\title{
Linguculturological properties of the use of phraseological units in teaching english
}

\section{Zaynab KARIMOVA ${ }^{1}$}

Gulistan State University

\begin{tabular}{l} 
ARTICLE INF0 \\
\hline Article history: \\
Received January 2021 \\
Received in revised form \\
15 January 2021 \\
Accepted 20 February 2021 \\
Available online \\
7 March 2021 \\
\hline Keywords: \\
Phraseology \\
Phraseological compounds \\
Phraseological compounds \\
Phraseological associations \\
Word-for-word phrases \\
Phraseological associations.
\end{tabular}

ABSTRACT

The article deals with the use of phraseological compounds in English, phraseological confusion, phraseological compounds, phraseological associations, phraseological combinationscomponents, the meaning of which is not related to the meaning of the whole unit, phraseological units, word-for-word phrases. It is also explained on the basis of examples.

2181-1415/C) 2021 in Science LLC.

This is an open access article under the Attribution 4.0 International (CC BY 4.0) license (https://creativecommons.org/licenses/by/4.0/deed.ru)

\section{Ingliz tilini o'qitishda frazeologik birliklardan foydalanishning linguculturological xususiyatlari}

\footnotetext{
Калит сўзлар:

Frazeologiya

Frazeologik chatishmalar, frazeologik qo'shilmalar, frazeologik birlashmalar, so`zma-so`z o’zlashtirilgan iboralar, frazeologik birlashmalar.
}

\begin{abstract}
АННОТАЦИЯ
Maqolada ingliz tilida frazeologik birikmalarning qo'llanilishi, frazeologik chatishmalar, frazeologik qo'shilmalar, . frazeologik birlashmalar , frazeologik chatishmalarkomponentlarining ma'nosi butun birlikning ma'nosiga aloqador bo'lmagan frazeologizmlar, so`zma-so`z o’zlashtirilgan iboralar haqida keltirilib o'tilgan. Bundan tashqari misollar asosida tushuntirilgan.
\end{abstract}




\section{Лингукультурологические фразеологических единиц \\ свойства \\ использования языка}

\author{
Ключевые слова: \\ Фразеология \\ Фразеологические \\ соединения \\ Фразеологические \\ соединения \\ Фразеологические \\ ассоциации \\ Дословные фразы \\ Фразеологические \\ ассоциации
}

\begin{abstract}
АННОТАЦИЯ
В статье рассматриваются вопросы употребления фразеологизмов в английском языке, фразеологической путаницы, фразеологических соединений, фразеологических ассоциаций, фразеологических сочетаний-компонентов, значение которых не связано со значением целой единицы, фразеологизмов, дословных словосочетаний. Это также объясняется на примерах.
\end{abstract}

Although the term "phraseology" is derived from the Greek word "frama" (phrasisexpression, speech wrapper), the term serves to express different meanings. For this reason, the term phraseology is used in linguistics in two senses: in the general sense of the phraseological units that do not exist in the language, and in the sense of the field in which such units are studied. So phraseology is the science of expressions. VV Vinogradov classifies phraseologies into three classes[1].

phraseological fusions.

phraseological units.

phraseological collocations or combinations.

Phraseological confusion-components are phraseologies that do not have the meaning of the whole unit[2]. Phraseological associations are made up of words that have a specific valence. One of the components of such phraseological units is used in its literal sense, the rest in the metaphorical sense. Phraseological associations are, to a certain extent, semantically indivisible.

For example: heavy father - the main role in the play; to kick the bucket - to die; Red tape - Phraseologism such as the bureaucratic method are idioms that have the same meaning as a whole.

Phraseological confusion is a completely different meaning of a phrase. But unlike phraseological compounds, their meanings are not understood from the meanings of their components.

Phraseologism learned from foreign languages are one of the sources that complement the phraseology of the English language. In particular, many phraseologies from Latin and French have been mastered. There are also phrases from Greek, Spanish, Italian and other languages. Most of the mastered phraseological combinations have a biblical character[3].

Literally learned phrases. This group is two small ones

divided into groups:

There are literal phrases in English, but some of them are original

not used in English. For example: baptism of fire.

There are some proverbs related to this small group: dead men dont bite - the dead 
does not bite (see no souls of the dead), the phrase is translated from English into Greek through Latin entered.

Phraseological confusions are phraseologies in which the meanings of the components are not related to the meaning of the whole unit. For example, heavy father the main role in a theatrical play, to kick the bucket - to die, red tape - the meaning of bureaucratic methods are phraseologies that give a single meaning that does not depend on the meaning of the words in it[4].

Phraseological confusion is a combination of words whose meaning has changed completely. But unlike phraseological compounds, their meanings are not understood from the meanings of their components, and metaphor-based semantic transitions lose their clarity. Phraseologisms such as to leave smb in lunch (to abaodon a friend when he is in trouble), to show the white feather (to betray one's cowardice), to dance attendenceon smb (to try and attract smb, to show exaggerated attention) can be an example. Phraseological compounds are phraseologies whose meaning is understood from the phraseological meaning of whole phraseological units. The transfer of meaning based on metaphor is clear and unambiguous. The lexical components of phraseological compounds are the most stable.

For example:

to look a gift horse in the mouth (to examine a present too critically, to find fault with smth one gained without effort),

- to ride a high horse (to behave a superior, haughtly, overbearing way),

- a big bug (a person to importance),

- a fish out of water (a person situated uncomfortably outside his usual and proper environment) Phraseologisms such as, for example, are examples of phraseological compounds. There is a lot of phraseology. Some of them are easy to translate and some are even international[5].

- For example, to know the way the wind blows - to know where the wind blows. .

Phraseological associations are words that have a specific valence. One of the components of such phraseological units is used in its literal sense, the rest in the metaphorical sense. Phraseological associations are to some extent semantically indivisible. Phraseological associations are partially altered combinations of words. The meaning of these phraseological units is easily understood from the meaning of the words that make them up.

To be at one's wits end, to be a goodhand at smth, to come off a poor second, to coma to a sticky end, to stick at nothing, gospel truth, bosom friend are examples of phraseological associations. In conclusion, the semantic aspects of occupational phraseological units show that in both languages they are related to human physical labor, which express concepts directly related to human labor activity.

\section{References}

1.Амосова Н. Н. Основы английской фразеологии. - М. 1963.-С.46-49.

2. Ахманова А. С. Словарь лингвистических терминов. - М.: СЭ.1966.-С.17-

3.Haydarov A., Choriyeva Z. Ingliz tilida frazeologik birliklarning semantikgrammatik va uslubiy xususiyatlari. Tilning leksik-semantik tizimi va qiyosiy tipologik izlanishlar: sinxroniya, dioxroniya materiallar to'plami. - T.: Muharrir. 2012. -B.8-10. 
4.Haydarov A., Jo'raqulova G. Frazeologik iboralar tarjimasi xususida. Tilning leksiksemnatik va qiyosiy tipologik izlanishlar: sinxroniya, dioxroniya materiallar to'plami. - T.: Muharrir. 2012. -B.10-13.

5.Jann Huizenga "Stories and idioms for real life" Oxford University Press.2000. 